POLITEIA
Politeia: Jurnal Ilmu Politik
Politeia: Jurnal Ilmu Politik, 10 (2) (2018): 69-78
ISSN 0216-9290 (Print), ISSN 2549-175X (Online)
Available online https://jurnal.usu.ac.id/index.php/politeia

\title{
Identitas Politik Catalonia dalam Simbol-Simbol Football Club Barcelona
}

\author{
Nanda Rizka Syafriani Nasution* \& Fernanda Putra Adella \\ Departemen Ilmu Politik, Fakultas Ilmu Sosial dan Politik \\ Universitas Sumatera Utara, Indonesia
}

Diterima Maret 2018; Disetujui Mei 2018; Dipublikasikan Juli 2018

\begin{abstract}
Abstrak
Sepakbola dan politik kini menjadi dua hal yang tidak dapat dipisahkan. Perkembangan sepakbola yang semakin pesat membuat olahraga ini menjadi sumber maupun alat untuk memperoleh tujuan tertentu. Tujuannya bisa bermacam-macam, mulai dari perolehan modal kapital sampai kekuasaan, eksistensi dan ideologisasi. Penelitian mengenai dua objek yang luput diperhatikan ini akan memakai data sekunder sebagai teknik pengumpulan data yaitu berupa literatur buku, jurnal lokal maupun internasional, serta bahan-bahan lain yang mendukung dan berkaitan dengan judul penelitian termasuk media massa serta menggunakan studi analisis kualtitatif sebagai analisis data. Terdapat tiga representasi simbol FC Barcelona terhadap identitas politik Catalan, yaitu: Pertama, bahasa dan bendera; Kedua, Catalan dan FC Barcelona memiliki kenangan kelam sejarah; Ketiga, simbol-simbol yang ada pada FC Barcelona adalah representasi semangat nasionalisme bangsa Catalan.
\end{abstract}

Kata Kunci: Identitas, Sepakbola, Simbol

\begin{abstract}
Abstrak
Football and politics are now two things that can not be separated. The development of football is increasingly rapidly making this sport a source and an instrument to obtain certain goals. The goal can be at variance, ranging from the acquisition of capital to power, existence, and ideologization. This research on two objects that missed will use secondary data as data collection technique that is in the form of book literature, local and international journal, as well as other materials that support and relate to the title of research including mass media and using study of qualitative analysis as technique in analyzing data. There are three representations of FC Barcelona symbols of Catalan political identity, namely: First, language and flags; Secondly, Catalan and FC Barcelona have dark memories of history; Third, the symbols that exist in FC Barcelona is a representation of the spirit of Catalan nationalism.
\end{abstract}

Keyword: Identity, Football, Symbol

How to Cite: Nasution, N.R.S. \& Adella, F.P. (2018). Identitas Politik Catalonia dalam Simbol-Simbol Football Club Barcelona, Politeia: Jurnal Ilmu Politik, 10 (2): 69-78

\footnotetext{
${ }^{*}$ Corresponding author:

E-mail: nandarizkasyafriani@gmail.com
} 


\section{PENDAHULUAN}

Sepakbola adalah hasil proses panjang peradaban yang bisa ditelusuri di banyak tempat di bumi sejak sebelum Masehi. Sejarah telah menetapkan bahwa beberapa peradaban paling awal telah memainkan beragam sepakbola rakyat. Beberapa menunjuk pada Amerika Tengah dan Amazon sebagai sumber kultur sepakbola, di mana permainan bola dimainkan oleh suku primbumi sudah sejak 1500 SM (Gullianoti,2006).

Mc Intosh mengemukakan bahwa bentuk terawal dari sepakbola telah dimainkan di zaman kuno, dalam permainan orang Romawi harspastum atau episcyros dari Yunani. Namun, kemungkinan besar, Cinalah yang paling bisa mengklaim punya sejarah sepakbola terkuno. Bola batu dibuat untuk ditendang dalam permainan di provnsi Shan Xi selama masa Neolitik. Lalu, cuju dimainkan selama Dinasti Han 9206 SM-220M) dengan aturan yang sangat mirip dengan sepakbola.

Lewat proses panjang sepakbola kemudian menjadi suatu entitas kebudayaan yang tidak dapat dipisahkan dalam kehidupan manusia. Sepakbola kini dikenal sebagai permainan yang indah karenna tidak hanya mengandalkan otot namun juga kecerdikan pemain di atas lapangan hijau dalam mengolah bola (Junaedi,2017).

Dalam Novel 11 Patriot, Andrea Hirata menuliskan:

"Sepak bola bukanlah sekedar dua puluh dua orang lelaki ganteng kurang kerjaan, berlari lintang pukang, bertumburan tak keruan, demi memperebutkan sebuah bola."
Sepak bola lebih dari sekedar menggiring bola, mencetak angka, dan meraih kemenangan. Psikologi, Seni, Sastra, Ekonomi, Politik, Bisnis, Agama, Budaya, Sejarah, Cinta, dan Patriotisme ada didalamnya.

Dalam ekonomi dan bisnis misalnya, sebagai salah satu hasil peradaban, sepakbola kini menjadi sebagai sebuah industri yang memiliki potensi besar untuk berkembang sebab jumlah penggemar yang jumlahnya milyaran (Foer,2017). Konsep industri sepakbola pada dasarnya adalah bagaimana sepakbola sebagai sebuah event mampu menguntungkan semua pihak yang terlibat mulai dari pemain, panitia pelaksana, klub, hingga penikmat sepakbola sebagai sebuah tontonan. Klub bisa memperoleh keuntungan dengan memanfaatkan berbagai aset yang dimilki klub seperti penjualan pemain, penjualan tiket pertandingan, penjualan berbagai merchandise dan bagaimana menarik minat investor atau perusahan swsata mau memberikan dana promosinya. Sepak bola dengan bisnis kapitalis dan perputaran uang di dalam transfer pemain, iklan, pasar taruhan, hingga urusan mode dan gaya hidup.

Dalam buku Sepak Bola, Pesona Sihir Permainan Global, Richard Giulianatti menyebut sepak bola telah menjadi mesin-mesin kebudayaan massa dan menjadi bagian dari budaya pop global. Sepak bola kini juga telah menjadi simbol kapitalisme global. Sebagai olah raga yang populer, sepak bola adalah bentuk serangan globalisasi yang imbasnya sangat massif. Amerika Serikat, yang dahulu rakyatnya menghujat sepak bola, justru menjadi tuan rumah Piala Dunia 1994. Dalam hal sepak bola, 
Amerika yang menyebut sepakbola sebagai soccer itu telah menjadi korban globalisasi (Foer, 2017).

Sebagai olahraga, sepakbola ternyata juga tidak dapat dipisahkan dari politik. Permainan ini menjelma menjadi suatu kekuatan entitas sosial tertentu untuk menggunakannya dalam mencapai suatu tujuan. Sepakbola menjadi barometer ideal dalam hubungan internasional, ketegangan antar bangsa, serta ambisi nasional. Ini bisa menjadi bukti ketidakberdayaan FIFA(Federation International Football Association) dalam slogan 'Kick Politic Out of Football'.

Sebagai contohnya Silvio Berlusconi berhasil mengendalikan AC Milan di puncak kejayaannya sebagai Perdana Menteri Italia setelah membeli klub tersebut pada tahun 1986. Atau pada kasus Paolo di Canio dan Christian Abbiati yang menyatakan dirinya sebagai fasis sementara Christiano Lucarelli mengaku sebagai komunis (Pandit, 2012).

Dalam lingkup yang lebih besar seperti pertarungan antar negara, FIFA bahkan tidak mampu menghalau politik lepas dari sepakbola. Padahal FIFA menjadi tujuan negara-negara yang baru merdeka langsung mencari legitimasinya dengan mengajukan syarat menjadi anggota yang jumlahnya lebih banyak daripada anggota PBB (Perserikatan BangsaBangsa) (Isharuddin, 2008).

Termasuk Spanyol sebagai negara yang masuk ke dalam daftar anggota PBB dan FIFA yang dapat dikatakan cukup berhasil dengan satu kali juara Piala Dunia (2010) dan tiga kali meraih gelar Piala Eropa (1964,
2008, 2012). Sepakbola bagi Spanyol dengan raihan gelar tim nasional maupun klub lokal - telah menjelma sebagai suatu bentuk dominasi kekuatan sosial ekonomi dan politik.

Namun, bagi FC Barcelona, salah satu klub sepakbola di negeri Matador tersebut, sepakbola bukan hanya tentang politik, ekonomi, bisnis dan uang. Barcelona Footbal Club adalah interpretasi tentang bagaimana sebuah revolusi dalam sepak bola dijalankan. Mereka adalah satu dari beberapa kesebelasan yang percaya bahwa gaya permainan dan sebuah kostum adalah suatu identitas.

Menyinggung soal identitias, di Indonesia sendiri, Reformasi 1998 mengubah wajah sepakbola Indonesia dengan identitas yang melekat dengannya. Klub perserikatan yang pada awalnya tidak dikenal menyeruak dalam peta sepakbola nasional. Terutama karena kejelian bupati atau wali kota yang melihat sepakbola sebagai aset daerah yang memiliki nilai politik dan ekonomi. Sebelum tahun 2011, anggaran pendapatan belanja dan daerah (APBD) bisa dialokasikan untuk menghidupi klub sepakbola profesional. Kuasa kepala daerah yang dilegalisasi oleh lembaga legislatif tingkat daerah menghidupi klub-klub dengan anggaran negara yang tidak sedikit (Jawa Pos, 2017).

Besinggungan dengan FC Barcelona yang merupakan klub yang berada di Catalonia, daerah otonomi khusus Spanyol adalah representasi wilayah Catalonia yang menyakili suku bangsa Catalan. Barca, sebutan FC Barcelona, didirikan pada tahun 1899 oleh sekelompok pemain Swiss, Inggris dan Catalan yang dipimpin oleh Joan Gamper , klub telah menjadi 
simbol budaya Catalan dan Catalanisme, yang mempunyai motto "Més que un club" (Lebih dari sebuah klub). Yang dapat diartikan bahwa klub Barcelona tidak seperti banyak klub sepak bola lainnya, para pendukung memiliki dan mengoperasikan Barcelona.

Barcelona adalah identitas nasional yang menyelamatkan sepakbola dari para pengecamnya. Barca juga menyelamatkan konsep nasionalisme itu sendiri. Dalam konteks negara bangsa, pertandingan Real Madrid melawan Barcelona menjadi arena pertarungan antara pemerintah pusat dan daerah yang seringkali bermuara pada isu separatime.Hal ini dapat terlihat dari mozaik, bendera dan nyanyian pendukung Barcelona secara langsung kepada pemerintah Spanyol yang menginginkan kemerdekaan dan itu dilakukan pada saat pertandingan di dalam stadion (Hanifan, 2017) .

Campu Nou, sebagai sebuah stadion, menjadi tempat sebuah identitas diagungkan. Camp Nou memberi warga Catalonia tempat untuk menjerit dan berteriak-teriak mencaci maki rezim penguasa dalam bahasa asli mereka yang dilarang. Barcelona di gambarkan bagai sebuah bangsa tanpa negara. Dan "Cules", sebutan penggemar Barca, adalah dari penduduk bangsa yang kolektif melawan dan memberontak.

$$
\text { Bagi siapapun pendukung }
$$

Barcelona, klub sepakbola ini dianggap dan dipahami sebagai "more than a club" karena inilah satusatunya klub sepakbola yang merepresentasikan daerah dan kebudayaannya sendiri (Novia, Marvin, 2013). Lewat kostum dan nyanyian,chants Can't del Barça dianggap sebagai seni, bendera keseblasan - senyera - sebagai psikologi warga Catalonia, dan catatan prestasi yang diraih adalah sastra yang tidak ada bandingannya.

Identitas dari FC Barcelona mengangkat nasionalisme masyarakat Catalonia dengan beberapa pemain merupakan pemain kunci dari tim nasional Spanyol yang berhasil menjuarai Piala Eropa 2008, Piala Dunia 2010, dan Piala Eropa 2012. Para pemain diantaranya adalah mereka yang asli Catalan seperti Xavi, Iniesta, Busquets, Fabregas, Pedro, Pique, Valdes, Puyol, dan Jordi Alba. Pencapaian mereka di Barcelona juga terbilang gemilang dengan membawa Barca meraih treble . Hal ini mengangkat popularitas klub dan para pemain ini juga ikut mengangkat nama bangsa Catalan.

Tidak semua pemain Barcelona adalah orang Catalan, bahkan tidak semua orang Spanyol, tapi bukan berarti mereka tidak memahami simbol-simbol dari Catalan adalah sebuah identitas dan FC Barcelona adalah tentara mereka (Siahaan, 2014). Gamper, salah seorang Presiden Barca saat mengajukan dirinya menjadi presiden klub sempat berkata:

"Barcelona tidak boleh dan tidak harus mati. Jika tidak ada seorang pun yang ingin mencoba, saya akan bertanggungjawab penuh dan menjaganya di masa depan"

Yang dapat diartikan bahwa peran FC Barcelona sangat vital dan dibutuhkan untuk mewakili identitas kesukuan dan karakter dari masyarakat Catalan.

Penulis ingin membuktikan bahwa simbol-simbol yang terdapat dalam klub sepakbola FC Barcelona menggambarkan identitas kesukuan 
Catalan tidak mampu membayangkan imaginasi sebagai sebuah bangsa di dalam negara kesatuan bersama Spanyol yang dianggap mereka berbeda meskipun telah menjadi kesatuan sejak 1714. Sebagaimana yang dikatakan Bennedict Anderson dalam bukunya Imangined Community menyebut bangsa sebagai "sebuah komunitas politis dan dibayangkan terbatas secara inheren dan memiliki kedaulatan."

Bangsa merupakan sebuah komunitas terbayang karena mustahil bagi individu anggotanya untuk benar-benar pernah berinteraksi. Lebih dari tiga ratus tahun Spanyol berdiri sebagai sebuah bangsa yang di dalamnya terdapat sebuah kebudayaan yang tidak pernah mengakui mereka bagian dari kesatuan yang utuh tersebut.

Sepakbola bagi rakyat Catalan bukan hanya sebagai panggung hiburan maupun hanya sekedar olahraga biasa namun telah menjelma sebagai alat mereka untuk berbicara kepada dunia bahwa mereka ingin berdaulat sebagai sebuah bangsa dan memisakan diri dari Spanyol. Sepakbola yang menjelma sebagai budaya yang tidak bisa dipisahkan dari politik kini menjadi menarik untuk diteliti dan Barcelona sebagai sebuah klub besar yang telah menjelma sebagai salah satu yang terbaik di dunia lewat simbol-simbol yang diperagakannya untuk menggambarkan identitas politik Catalonia.

\section{METODE PENELITIAN}

Penelitian ini adalah bersifat diskriptif. Pengumpulan data dengan teknik penelitian studi pustaka.
Analisis data menggunakan analisis kualitatif.

\section{HASIL DAN PEMBAHASAN}

Simbolitas yang akan dijelaskan menjadi senjata FC Barcelona untuk terus membangun kesadaran identitas yang sudah dimilki oleh rakyat Catalan. Suatu identitas dijelakan oleh Ferdinand Saussure sebagai tanda dan makna yang menjadi sebuah ilmu lain yang mengkaji tanda-tanda dalam kehidupan sosial yang menjadi bagian dari psikologi sosial yang disebut sebagai sémiologie. Semiotik berupa tanda dan makna inilah yang dimainkan dengan baik oleh FC Barcelona. Keyakinan akan FC Barcelona yang dapat mewujudkan keinginan rakyat Catalan yang ingin memisahkan diri dari Spanyol dapat dilihat dari beberapa ciri-ciri klub Catalan berupa simbol yang menjadi suatu tanda dan mempunyai makna tersendiri.

Slogan "lebih dari sekedar Klub" mengekspresikan komitmen yang telah dipertahankan Futbol Club Barcelona dan masih bertahan di luar apa yang termasuk dalam ranah olahraga. 'Mes Que Un Club' diciptakan oleh presiden Barcelona tahun 1986, Nacis de Carreras, sekaligus menjadi orang pertama yang mengucapkan slogan tersebut dalam pidato penerimaan presiden klub pada Januari 1968 (Novia, Marvin, 2013). Selama bertahuntahun, komitmen ini secara khusus mengacu pada masyarakat Catalan, yang selama beberapa dekade abad ke-20 tinggal di bawah kediktatoran yang menganiaya bahasa dan budayanya. Dalam keadaan seperti ini, Barca selalu mendukung sentimen 
Catalan, dan pembelaan bahasa dan budayanya sendiri.

Itu karena ini, meski bahasa Catalan bukan bahasa resmi, bahwa pada tahun 1921 klub tersebut merancang undang-undangnya dalam bahasa Catalonia. Di era inilah pula, pada tahun 1918 klub tersebut mengajukan petisi untuk undangundang otonomi untuk Catalonia, yang diminta dari semua sektor gerakan catalanista.

Posisi

klub

tersebut

menyebabkan pembalasan dari pihak berwenang Spanyol dan ditutup selama enam bulan di bawah kediktatoran Primo de Rivera. Selama Republik Spanyol Kedua, klub tersebut mengintensifkan pesan implikasinya dengan budaya dan institusi Catalonia sendiri. Presiden Josep Suñol memimpin proses ini dengan menggunakan slogan "olahraga dan kewarganegaraan", tujuannya untuk menyiratkan olahraga dalam urusan sosial dan budaya negara tersebut.

Sejak saat Barca didirikan, klub memiliki lambang sendiri sehingga para pemain dengan bangga mengenakan kostum mereka. Itu adalah lambang kota Barcelona, bentuk berlian dibagi menjadi empat penjuru, dengan mahkota dan kelelawar di atas, dan dikelilingi oleh dua cabang, satu pohon salam dan satu telapak lainnya. Ini, bahkan pada tahap awal seperti itu, adalah cara untuk mengekspresikan hubungan klub dengan kota tempat ia dilahirkan (FC Barcelona, 2017), maka tidak heran jika FC Barcelona mendapat simpati lebih dari rakyat Catalonia.

Gambar 1.Perkembangan logo FC Barcelona
Sumber:

https://www.fcbarcelona.com/club/identity /card/the-crest
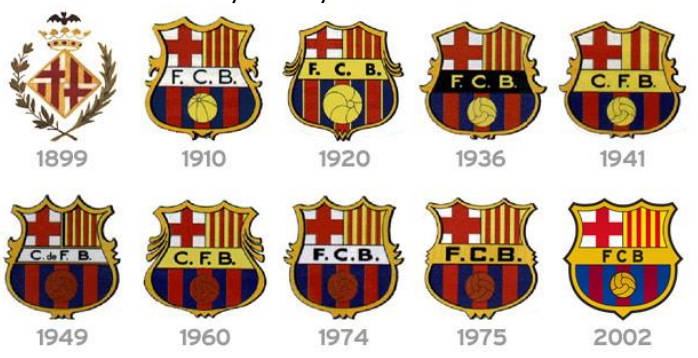

Gambar 2. Bendera Catalan yang terdapat pada Logo FC Barcelona

Sumber: google image

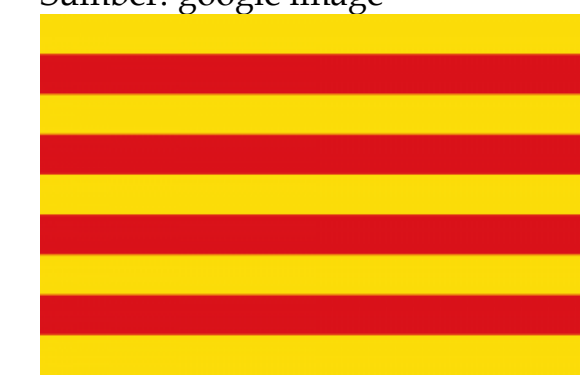

Gambar 3. Salib Saint George yang juga Terdapat di Logo FC Barcelona Sumber: google image

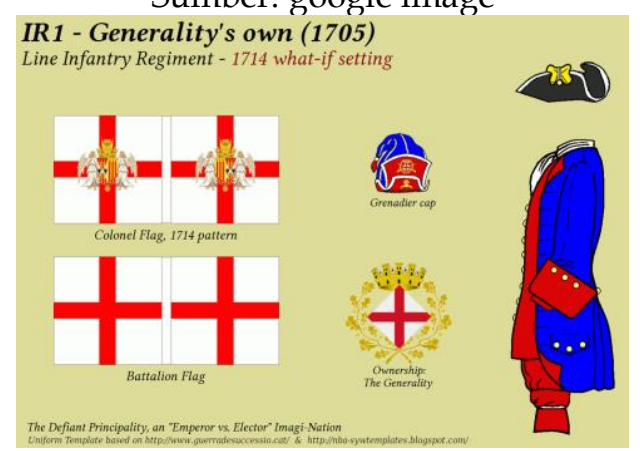

Untuk warna pada kostum, biru dan garnet telah tampil di kostum Barca Selama lebih dari seratus tahun dan Club dikenal secara luas sebagai 'Blaugrana' atau 'Azulgrana' yang mengacu pada nama-nama warna Biru-Marun dalam bahasa Catalan. Namun, meskipun kostum Barca tetap relatif konstan dalam desain selama bertahun-tahun, celana pendek tim putih selama sepuluh tahun pertama sejarah klub, lalu beralih ke warna hitam, dan baru biru dari tahun 1920an dan seterusnya.

Gambar 4. Kostum FC Barcelona 


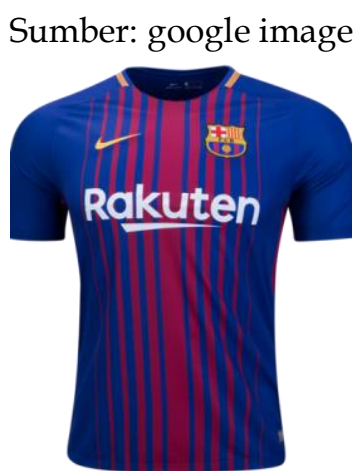

Hal ini direpresentasikan di situs resmi FC Barcelona, meskipun sekarang sudah dimuat dengan beberapa bahasa sesuai dengan penyesuaian klub tentang kebutuhan penggemar yang sudah tersebar diseluruh dunia. Tidak hanya mempromosikan mereknya sendiri, namun FC Barcelona juga mempromosikan Catalonia. Di situs klub, Laporta menunjukkan bahwa "keinginannya adalah bahwa Barca tetap menjadi alat yang selalu ada bagi negara ini untuk memproyeksikan nilai-nilai dan pengetahuan kita tentang Catalonia ke dunia pada umumnya (Shobe, 2006).

Media olahraga Barcelona, khususnya Sport, menunjukkan bahwa FC Barcelona Bahasa Catalan juga tercermin dalam lagu kebangsaan FC Barcelona 'El Cant del Barça'. Lagu ini bukanlah lagu kebangsaan pertama yang dimiliki Club selama sejarahnya yang panjang. Ini pertama kali dilakukan pada tanggal 27 November 1974, sebelum pertandingan yang menandai akhir perayaan ulang tahun ke-75.

Sebuah paduan suara 3.600, yang dilakukan oleh Oriol Martorell, berkumpul di lapangan untuk pertunjukan publik pertama dari lagu kebangsaan yang baru. Kata-kata itu ditulis oleh Josep Maria Espinàs dan Jaume Picas, dan musiknya disusun oleh Manuel Valls. Lagu itu semakin populer. Para penggemar menyukai kenyataan bahwa mereka dapat bertepuk tangan pada waktunya dengan ritme yang mudah diingat, dan kata-kata itu dengan sempurna menggambarkan nilai-nilai pendukung Barca, terutama semangat menyambut orang luar ke masyarakat Catalan, sebuah semangat yang tercermin sepanjang jalan melalui keanggotaan klub (FC Barcelona, 2017).

Semiologi (atau semiotika) yang telah dijelaskan oleh Saussure kemudian dikembangkan oleh Roland Barthes dengan menyelidiki hubungan antara penanda dan petanda pada sebuah tanda. Hubungan penanda dan petanda ini bukanlah kesamaan (equality), tetapi ekuivalen. Bukannya yang satu kemudian membawa pada yang lain, tetapi korelasilah yang menyatuka keduanya. Berbagai data dan fakta yang menampilan begitu banyak hal yang ada di dalam FC Barcelona.

FC Barcelona yang terbentuk pada tahun 1899, sejak awal hingga kini, telah menjadi ikon atau simbol dari rakyat Catalan. Desain logo klub memua bendera Senyera yang identik dengan catalan. Bangasa Catalan digunakan sebagai bahasa resmi klub. Dan FC Barcelona pun menjadi perjuanagan simpatisan partai republik sosialis pada era perang saudara dan pergerakan kemerdekaan Catalan di era modern (Novia, Marvin, 2013).

Barthes yang melihat aspek lain dari penandaan yaitu "mitos" yang menanda suatu masyarakat menjadikan "Mitos" terletak pada tingkat kedua penandaan jadi setelah terbentuk sistem tanda-penanda- 
petanda, tanda tersebut akan menjad penanda baru yang kemudian memiliki petanda kedua dan membentuk tanda baru. Dari apa yang telah digambarkan diatas, dapat dikatakan Nasionalisme menurut Barthes adalah apa yang dinamakan dengan mitos.

Mitos adalah bagaimana kebudayaan menjelaskan atau memahami beberapa aspek tentang realitas atau gejala alam. Mitos adalah suatu wahana dimana suatu ideologi berwujud (Wibowo, 2013). Catalonia yang secara kesejarahan merupakan wilayah independen di Semenanjung Iberia yang terletak di antara Spanyol dan Portugal, dengan bahasa, undang-undang serta kebiasaannya yang berbeda. Saat perang Suksesi Spanyol pimpinan Raja Philip IV yang berakhir dengan kekalahan Valencia pada tahun 1707, di Catalunya pada tahun 1714, dan kepulauan terakhir pada tahun 1715, kemudian menghasilkan kelahiran Spanyol modern.

Mitos adalah anggapan

bedasarkan observasi kasar yang digeneralisasikan dalam masyarakat. Apa yang dimaknai oleh bangsa Catalan sebagai identitas mereka dijelaskan dengan baik oleh FC Barcelona dengan juga memakai simbol yang sama dengan apa yang dimaknai oleh Catalan seperti bendera dan bahasa. Apalagi selama era kediktatoran Miguel Primo de Rivera dan terutama Francisco Franco (19391975), semua budaya regional ditekan termasuk penggunaan bendera Catalonia. Semua bahasa daerah yang dipakai di wilayah Spanyol, kecuali bahasa Spanyol (Castilla), secara resmi dilarang.
Barcelona juga masuk pada perjuangan Catalonia dengan ikut merasakan kekejaman fasisme Franco. Ketika pasukan Franco melancarkan serangan pamungkas untuk menaklukkan Catalonia, mereka bom gedung tempat penyimpanan pialapiala keseblasan. Sesudah membungihanguskan peralatan fisik klub, kubu Franco melucuti identitas Barca. Franco bahkan memaksa Barcelona untuk mennganti nama klub mereka dari "Football Club Barcelona" menjadi "Club de Football Barcelona" yang itu terwujud dengan perubahan logo mereka.

Bangsa dibayangkan sebagai sesuatu yang pada hakikatnya bersifat terbatas karena bahkan bangsa-bangsa paling besar pun, yang anggotanya mungkin semilyar manusia, memiliki garis-garis perbatasan yang pasti memiliki elastis. Diluar batasan itu adalah bangsa-bangsa lain. Tak satu bangsa pun membayangkan dirinya meliputi seluruh umat manusia di bumi (Anderson, 2002).

Namun, para penggemar Barcelona, entah mereka sebagai orang Catalan atau tidak, dengan sadar atau tidak, dapat merasakan apa yang dirasakan oleh bangsa Catalan dengan ekternalisasi penginternalan yang telah dilakukan berulang-kali baik itu di stadion, maupun di media yang terus menggambarkan simbolsimbol yang mereka percayai.

Sepanjang sejarah FC Barcelona, klub telah terlibat dalam momen penting dalam sejarah Catalunya dan telah memperkuat posisinya di masyarakat Catalan. Meskipun tidak ada keraguan bahwa Barca melihat diri mereka sebagai klub Catalan sebelum Franco berkuasa, peran yang dimainkan klub tersebut secara drastis 
diubah oleh kediktatoran. Barça menjadi ruang yang sangat penting untuk bekerja dan menjaga identitas Catalan. Barça mampu berkembang karena tidak dianggap sebagai organisasi politik dan karena itu tidak dipandang sebagai ancaman bagi negara.

Sebagai gantinya, ia diizinkan hadir sebagai ruang di mana identitas Catalan dapat menemukan suara kolektifnya. Sementara Catalan terus berbicara di lingkungan pribadi, tautan yang diberikan Barca ke ranah publik memungkinkan pemeliharaan kesadaran Catalan kolektif. Pentingnya solidaritas, terutama pada masa pembungkaman dahulu, yang bisa saja menghasilkan isolasi. Barca mengembangkan rasa identitas Catalan bersama. Rasa identitas Catalan bersama ini didukung dan dipupuk oleh aktivisme komunitas yang dimainkan oleh klub.

Posisi Barca sebagai salah satu proyeksi internasional identitas Catalan yang paling penting. Barca dikenal di seluruh dunia sebagai lebih dari sekedar Klub, yang mewakili wilayah/negara tempat ia berada. Permainan Barca disiarkan di televisi di seluruh dunia, khususnya Liga Champions, mungkin memberikan gagasan tentang negara Catalan yang otonom.

Pada akhirnya, bangsa
dibayangkan sebagai sebuah
komunitas, sebab tak peduli akan
ketidakadilan yang ada dan
penghisapan yang mungkin tak
terhapiskan dalam setiap bangsa,
bangsa itu sendiri selalu dipahami
sebagai kesetiakawanan yang masuka
mendalam dan melebar-mendatar.
Pada akhirnya, selama dua abad
terakhir, rasa persaudaraan

inilahyang memungkinkan begitu banyal orang, jutaan jumlahnya, bersedia jangankan melenyapkan nyawa orang lain, merenggut nyawa sendiri pun rela demi pembayangan tentang yang terbatas itu (Anderson, 2002).

\section{SIMPULAN}

Bedasarkan simbol-simbol muali dari slogan 'more than a club', logo dan warna, bahasa, serta stadion, penelitian ini berkesimpulan bahwa FC Barcelona jelas mengintrepertasikan identitas rakyat Catalan. FC Barcelona juga memikat simpati khalayak dengan meyakinkan bahwa gagasan mereka yang berada terus dibelakang masyarakat Catalan adalah baik. Persamaan sejarah dalam korban tindakan fasisme dan ketakutan akan masa lalu serta industrialisasi yang menunjukkan kemampuan akan berdirinya sebuah negara membuat FC Barcelona bertindak untuk memberikan perhatian yang lebih terhadap kemajuan sebuah bangsa yang mereka sebut sebagai Catalan.

\section{DAFTAR PUSTAKA}

Anderson, B. (2002). Imagined Comunity: Komunitas-Komunitas Terbayang. Yogyakarta: INSIST

Foer, F. (2017). Memahami Dunia Lewat Sepakbola. Tangerang: Marjin Kiri Giulianotti, R. (2006). Sepakbola: Pesona Sihir Permainan Global. Yogyakarta: Apeiron Philotes

Siahaan, P. (2014). The Big Pang Theory: Talking Nonsense about Footbaall. Jakarta: Elex Media Komputindo Hunter S. (2006). Place, Sport and Globalization: Making sense of la marca Barça. 
Hanifan, A.F. (2017). Jenderal yang Abadi dalam Perseteruan Real Madrid-Barcelona dalam https://sport.detik.com/aboutth egame/pandit/d-

2557384/jenderal-yang-abadidalam-perseteruan-real-madridbarcelona diakses pada 18 Desember 2017 Pukul 23.25 WIB

Futbol Club Barcelona. (2017). The Crest dalam https://www.fcbarcelona.com/c lub/identity/card/the-crest diakses pada 21 Januari 2018 Pukul 00.58 WIB

Futbol Club Barcelona. (2017). The history of the Barça anthems dalam https://www.fcbarcelona.com/c lub/identity/card/the-anthems diakses pada 21 Januari 2018 pukul 00.54 WIB 